Корчакова Наталия, доктор психологических наук, профессор кафедры возрастной и педагогической психологии Ровенского государственного гуманитарного университета https://orcid.org/0000-0003-1164-3370

Безлюдная Валентина кандидат педагогических наук, профессор кафедры возрастной и педагогической психологии Ровенского государственного гуманитарного университета https://orcid.org/0000-0003-3276-3427

DOI https://doi.org/10.35619/praprv.v1i16.207

\title{
УСТАНОВКИ СТУДЕНЧЕСКОЙ МОЛОДЕЖИ ОТНОСИТЕЛЬНО НЕЗАПЛАНИРОВАННОЙ БЕРЕМЕННОСТИ
}

\begin{abstract}
Анотація У статті розглядається питання ставлення молоді до незапланованої вагітності. Вивчення психологічних основ прийняття жінкою рішення про долю ненародженої дитини має велике сочіально-етичне значення для сучасного суспільства. В дослідженні брали участь 86 респондентів. Середній вік учасників 20,2 роки. Для вивчення їхнього ставлення до ситуації незапланованої вагітності ми використовували Анкету рольових орієнтацій дітонародження (РОД) (автор Родштейн), Анкету "Незапланована вагітність" (автор Корчакова) та стандартизоване інтерв'ю для вивчення репродуктивних установок (автор Каримова). Наші результати показали, щзо молоді українки мають чітко сформовані сімейно- та дітоцентровані орієнтацій. Вони досить стримано ставляться до ідеї ичивільного шлюбу (близько 32,9\% продемонстрували негативне ставлення і лише 12\% задекларували високий рівень прийняття такого типу взаємин). Однак, вони не засуджують дошлюбні сексуальні стосунки (лише 8\% учасників ставляться з осудом до таких відносин). Змістовий аналіз емоційних станів, пов'язаних з усвідомленням факту небажаноі вагітності, виявив домінування негативних думок та емоцій серед дівчат. Вони заявляли про страх, стрес, паніку, розгубленість. Однак 35,6\% респондентів мають позитивні асоціації з народженням дитини. Всі установки ми розділили на 3 підгрупи: позитивні, негативні та філософсько-нейтральні.
\end{abstract}

Беручи до уваги вплив сочіальних та моральних иінностей на процес прийняття рішення, ми попросили учасників оцінити низку соціальних изінностей: «особиста свобода», «економічний добробут», «діти», «професійний розвиток», «сім'я» $i$ «любов». Наші респонденти вважали найціннішими серед них: «сім'ю», «любов» та «дітей». Такі сімейноорієнтовані установки лежать в основі домінування у відповідях респондентів ідеї «народити дитину» (86\% дівчат), навіть якщо партнер не готовий надати підтримку, в порівнянні з ідеєю «позбавитися небажаної вагітності» (14\%). Варто зазначити, шуо варіант «народити та віддати дитину на усиновлення» не був обраний жодною учасницею. Молоді жінки не розглядають цеей варіант як спосіб розв'язання проблеми.

Ще одним ситуачійним фактором, який, на наш погляд, може вплинути на вибір жінки, були характеристики потенційного батька. Наші респонденти оцінили доцільність народження дитини з трьома типами чоловіків: "коханий», «випадковий партнер» та «кривдник». Можна було передбачити, щзо перший тип був високо оцінений з точки зору можливості мати спільну дитину. Дивно, але у випадку випадкового партнера чи, навіть, кривдника менше половини респондентів вважали за краще не мати дитину з такими батьками (38,4\% та 48,8\% відповідно). Більще того, навіть у випадку вагітності в 
результаті сексуального нападу близько 13,9\% жінок заявили про високий рівень доцільності народжувати.

Важливими напрямками подальших досліджень ми вважаємо вивчення установок у чоловічій вибіриі щуодо факту незапланованої вагітності; вивчення впливу певних демографічних чинників (наприклад, проживання в сільській місчевості, невеликих містах, мегаполісах) на формування установок; проведення крос-культурних досліджень.

Ключеві слова: незапланована вагітність, репродуктивні установки, сочіальні изнності.

Постановка проблемы. Психологические аспекты материнства широко обсуждаются в современном научном пространстве. Исследуется природа и сущность чувства материнства, особенности его развития и детерминация, исторические и социокультурные истоки. Особое внимание уделяется вопросам, ставящим под угрозу нравственные устои человеческого общества - отказ от материнства, депривация прав будущего ребенка на жизнь, воспитание, материнскую любовь и заботу. В этой связи, в психологических исследованиях предпринимаются попытки изучения процесса принятия женщиной решения о рождении ребенка, формирования ее готовности к материнству, присвоения материнской позиции, возникновения отклонений в осознании своей репродуктивной и воспитательной функции (Шишук, 2010).

Анализ последних исследований по проблеме. Наступление беременности - начало активной фазы формирования конструкта «материнская сфера». Человек не властен над процессом естественного зачатия, поэтому ощущение зарождающейся жизни может стать не только неожиданным для обоих сексуальных партнеров, но и нежелательным. Психологические аспекты нежелательной беременности в психологической науке, чаще всего изучаются в контексте возникновения ранней беременности (Туманова, 2009) и анализе вопросов планирования семьи в супружеской паре. И в первом, и во втором случаях возникает множество проблем, ведущих к нарушению гармонии личностного развития и возникновению предпосылок девиантного материнства. Решение о сохранении-прерывании нежелательной беременности, в обоих случаях, преимущественно, принимается коллегиально семейными коллективами: родительской семьей девушки-подростка или партнерами уже состоявшегося брачного союза.

Наряду с этим, в жизненной практике присутствуют ситуации, когда ответственное решение о сохранении зарождающейся жизни девушка вынуждена принимать преимущественно самостоятельно. Речь идет о вынашивании и рождении внебрачного ребенка, зачатого вследствие случайных связей или любовных отношений. Когнитивномотивационное пространство рассуждений и переживаний девушки отличается и от горестно-тревожных мыслей малолетней мамы, и от размышлений зрелой женщины, уже реализовавшей себя в материнстве. Изучение психологических основ принятия женщиной решения о судьбе будущего ребенка имеет огромное социально-этическое значение. Прерывание незапланированной беременности неоднозначно воспринимается обществом: от его полного запрета и криминального преследования, до признания права женщины на принятие решения и его правового регулирования. В любом случае, пагубность последствий для общества, для несостоявшейся жизни, физического и психологического здоровья женщины обуславливает целесообразность психологического изучения и сопровождения процесса принятия решения в этом деликатном вопросе.

Возникновение нежелательной беременности существовало в человеческом обществе всегда. Соответственно, предпринимались и попытки ее прерывания. Еще в работах Аристотеля, аборт рассматривается как путь планирования семьи, при условии его своевременного осуществления - «...прежде чем у зародыша появится чувствительность и жизнь» $(2020$, с. 153). В последние годы количество абортов в мире сократилось, но и сейчас они исчисляются миллионами. По данным ВООЗ ежегодно в мире делается 40-50 миллионов абортов, т.е. 125 тысяч ежедневно. В Украине на протяжении последних 20 лет этот показатель существенно снизился. Из 1 млн. 19 тыс. в 1990 г. до 434 тыс. у 2000 г. и, 
наконец, до 46,6 тыс. в 2018 году. К сожалению, в 2019 году количество абортов снова резко увеличилось до 74, 6 тыс. (Данілова, 2019). При этом, как и прежде, «нежелательная» беременность в 85-92\% случаев заканчивается искусственным ее прерыванием.

Целью сообщения является изучение ценностных ориентаций девушек относительно такого социо-биологического явления как «незапланированная беременность». В работе использовались методы: Опросник ролевых ориентаций деторождения (РОД) (авт. Родштейн); Опросник «Незапланированная беременность» (авт. Корчакова), Стандартизированное интервью для исследования репродуктивных установок (авт. Каримова);

Изложение основного материала исследования. В исследовании принимали участие студенты высших учебных заведений Украины. Общий объем выборки составил 86 респондентов, средний возраст 20,2 года.

Большинство участниц исследования незамужние $(93,4$ \%), остальные $(6,6 \%)$ состоящие в браке. Все девушки ориентированы на создание традиционной семьи. Проживание в гражданском браке значительное число из них не одобряет (41,9\%). При оценивании меры согласия на пребывании в незарегистрированных отношениях (по 10бальной шкале), высокий уровень принятия зафиксирован только у 12,8 \% опрошенных. (см. рис 1).

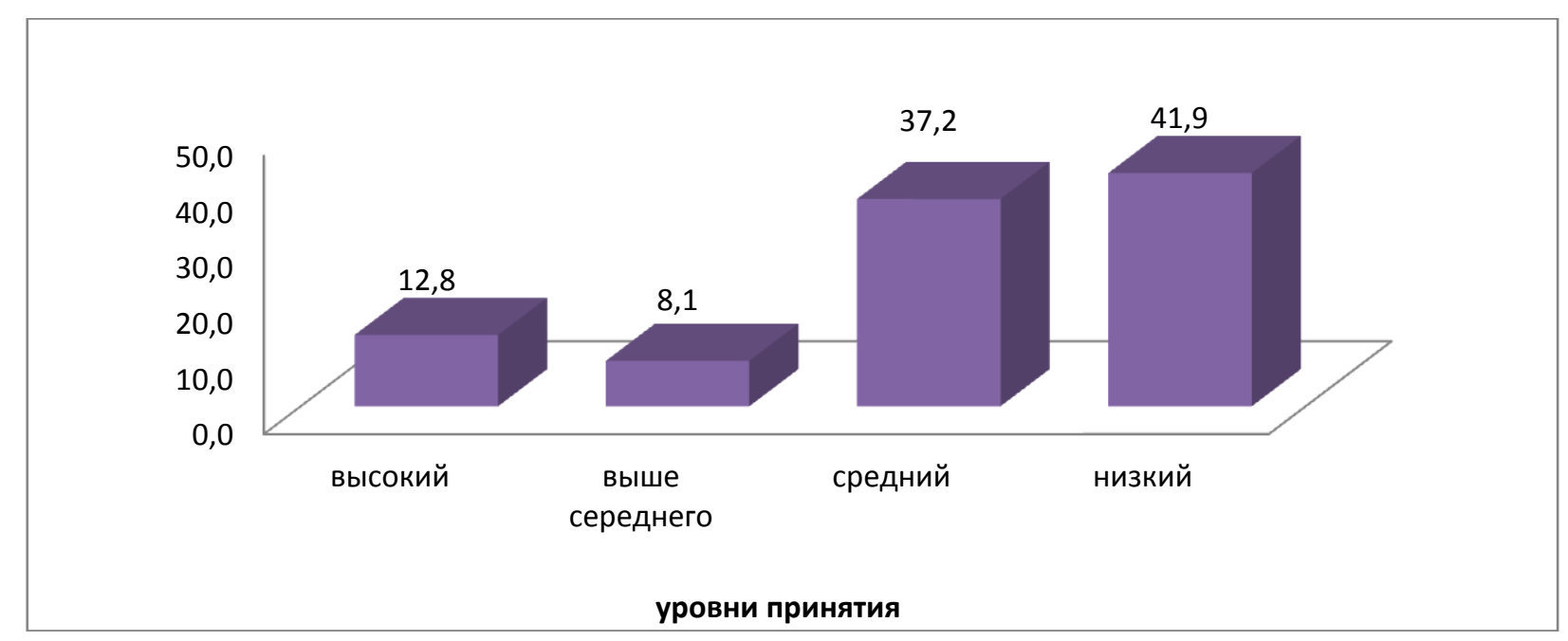

Рис. 1. Дифференциация выборки по уровню принятия-отвержения гражданского брака

Ориентация на семейные ценности подтверждается и позициями опрошенных, которые они задекларировали при выполнении задания на ранжирование жизненных ценностей. Среди шести ценностей - «личностная свобода», «материальное благополучие», «дети», «профессиональное становление», «семья» и «любовь» - первые ранговые позиции заняли семейно ориентированные: I место - «семья», II - «любовь» и III - «дети». Близкими по содержанию являются и размышления девушек о смысле жизни. По мнению половины участниц (55,7\%) это - дружная, любящая семья и дети. Даже такие важные для каждого человека цели как самореализация («найти себя», «оставить след на Земле») и нравственнодуховное развитие («стать человеком с большой буквы»; «прийти к Богу», «быть в гармонии с миром») отошли на второй план и прозвучали в ответах только трети участниц опроса (29,5\%). При этом, рождение ребенка ассоциируется у девушек с уникальным, ни с чем не сравнимым явлением. В их описаниях ребенок - это «чудо», «сокровище», «восход солнца», «приход весны», «дар небес», или же «новый этап», «новая эра», «наиболее важный момент в жизни женщины».

Перейдем к анализу позиций девушек, относительно рождения детей в ситуации незапланированной беременности. В целом, они распались на три составляющие: непринятие (35,6\%), нейтрально-философское понимание $(28,9 \%)$, позитивное отношение (35,5\%). 
Анализ ассоциативных рассуждений респондентов свидетельствует, что треть их высказываний ориентированы на описание отрицательной сущности явления. В суждениях упор обращен на эмоциональную напряженность ситуации. Незапланированная беременность - «мой страшный сон», «самое ужасное, что может со мной случиться», «большой стресс», «ужас для всех». Другим направлением негативно ориентированных рассуждений было уравнивание понятий «незапланированная» и «нежелательная» беременность». Позитивно ориентированное восприятие незапланированной беременности прозвучало в трети суждений $(35,5 \%)$. Девушки упоминали права ребенка на жизнь, его непричастность к случившемуся, акцентировали его ценностную сущность («это не вина ребенка», «он имеет право на жизнь», «внеплановость - не повод лишать жизни»). Категория нейтрально-философского отношения к нежелательной беременности объединила рассуждения о том, что «такое случается», что «с этим можно справиться», «случилось, так случилось», «Ок!».

Для понимания процесса переосмысления молодыми людьми жизненных ценностей обратимся к изучению эмоциональной составляющей ситуации. Участникам опроса было предложено назвать основные эмоциональные состояния, которые могут возникнуть у девушки при осознании факта наступившей беременности. Всего студентами было выделено 35 эмоциональных состояний. Их факторизация позволила сгруппировать состояния в шесть основных групп: растерянность (31\%), страх (29\%), отчаяние $(22 \%)$, социальные эмоции (11\%), нервозность (3\%) и, наконец, удовлетворенность (3\%.)

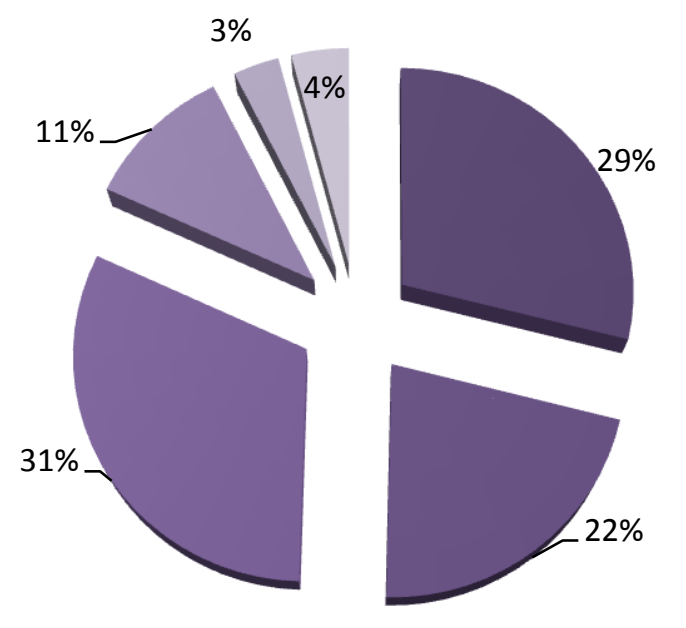

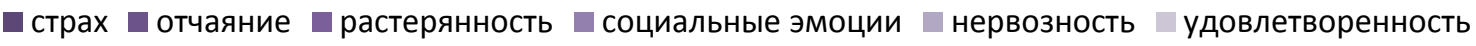

\section{Рис.2. Основные группы эмоциональных форм реагирования при осознании факта незапланированной беременности}

Фактор «растерянности» объединил позиции, указывающие на возникновение высокого уровня тревожности, беспокойства, волнения, разочарования, грусти и депрессии. Непредвиденность ситуации порождает у женщины ощущение неопределенности, потери возможности управлять жизненными процессами. Закономерно, что такие эмоциональные состояния осложняют процесс принятия конструктивного решения, провоцируют импульсивность, безволие и непродуманность поведения. Половину всех суждений об эмоциональном восприятии беременности составили указания на страх (22\%), как основной тип реакции, и наличие группы эмоций отчаяния (22\%) в виде безысходности, истерики, стресса, шока, паники. Одну из подгрупп эмоций мы обозначили как переживание социально-эмоциональных реакций. Сюда вошли суждения трех типов: состояния, обозначающие эмоциональные взаимоотношения с близкими людьми (стыд, вина, боязнь 
осуждения); новое отношение к партнеру (агрессия, злость, разочарование) и стремление к самоизоляции (недоверие, замкнутость). Очень показательным есть тот факт, что, будучи детоцентрированными, наши респонденты при описании эмоциональной составляющей наступившей беременности категорию позитивных переживаний используют только в отдельных случаях. Фактор «удовлетворение, счастье, радость» составил 3\% от общего количества суждений.

Можно сделать вывод, что в случае беременности, эмоциональный фон переживаний незамужней девушки будет скорее отрицательным, нежели амбивалентным, каким он является у женщин, пребывающих в браке. В условиях растерянности, отчаяния, страха девушка должна принять важное решение, которое коснется не только ее дальнейшей судьбы, но и жизни еще нерожденного ребенка.

На процесс принятия решения существенное влияние оказывает ситуативная составляющая, и, прежде всего, то, кем является отец ребенка для потенциальной матери. В исследовании рассматривались три ситуации: отец - случайный знакомый; отец - любимый человек; отец - преступник, совершивший сексуальное насилие над девушкой. Анализируя ситуацию беременности от любимого человека, большинство участниц опроса $(67,4,1 \%)$ указывают на высокий уровень целесообразности сохранения маленькой жизни, обозначая свою позицию 8-10 баллами (при возможной максимальной оценке 10). Результаты представлены в табл.1.

Таблий 1.

\section{Дифференциация выборки по уровню декларируемой целесообразности рождения ребенка в зависимости от партнера (в \%)}

\begin{tabular}{|c|c|c|c|}
\hline \multirow{2}{*}{$\begin{array}{l}\text { цровень } \\
\text { целообразности }\end{array}$} & \multicolumn{3}{|c|}{ Особенность партнера } \\
\hline высокий & 67,4 & 34,9 & насильник \\
\hline средний & 26,7 & 26,7 & 37,0 \\
\hline низкий & 5,8 & 38,4 & 48,8 \\
\hline
\end{tabular}

Средние показатели установок девушек относительно целесообразности рождения ребенка в зависимости от характеристик потенциального отца соответственно: «любимый человек» - $M=7,93$; «случайный партнер» - $M=5,42$; «насильник» - $M=4,20$. Дисперсионный анализ подтверждает статистическую достоверность разницы средних в этих группах $F(2 ; 256)=40,7$ ( $\leq 0,001)$ Необходимо подчеркнуть, что ориентация на рождение ребенка обусловлена не только надеждой девушки на получение поддержки и понимания со стороны партнера. Рефлексируя ситуацию беременности от любимого человека, большинство участниц опроса $(88,5 \%)$ считают, что сохранили бы жизнь ребенка даже при условии неготовности их партнера к брачным отношениям. Определяя свои позиции в триадическом пространстве: «прервать беременность - родить с последующей отказом от ребенка - родить ребенка и воспитывать его», большинство девушек $(85,2 \%)$ избрали позицию в пользу рождения и воспитания ребенка. Ни одна из участниц опроса не посчитала возможным избрать путь рождения ребенка с последующей его передачей в органы опеки.

Значимым является тот факт, что из четырех предложенных вариантов поведения при обнаружении беременности (сообщить партнеру, обратиться за советом к родителям, принять решение самостоятельно, обратиться к друзьям) 90\% участниц опроса избрали первую позицию, и только в отдельных случаях $(8,2 \%)$ была задекларирована позиция самостоятельного решения проблемы. В ситуации случайного знакомства, позицию целесообразности рождения ребенка декларируют 39,3\% участниц. Сохранение ребенка, зачатого в результате сексуального насилия, целесообразным считают только $18 \%$ девушек. Отличаются и позиции, которые в реальной ситуации выступают основой принятия решения об аборте - убеждения о нецелесообразности сохранения беременности. Если в ситуации отношений с любимым человеком низкий уровень целесообразности рождения ребенка 
задекларировало только несколько участниц опроса $(6,6 \%)$, то последствия сексуальной связи со случайным партнером повышают этот показатель до $41 \%$. В ситуации насилия половина респондентов (51\%) воспринимает ее как основание для прерывания беременности. Сформированность позиций подтверждается и ответом девушек на прямой вопрос: «Родили бы вы ребенка после изнасилования?». Половина опрошенных (50,8\%) дали ответ с отрицательным контекстом («нет» или «скорее нет»).

Размышляя о мотивах, которые могли бы способствовать решению о сохранении жизни ребенка при незапланированной беременности, девушки, прежде всего, обращают внимание на свое отношение к детям, сформировавшиеся социально-нравственные установки и отрицательные последствия аборта для здоровья (прежде всего репродуктивного). К категории «отношение к детям» были отнесены идеи принятия ребенка как ценности, любви к нему, признание отсутствия его вины («дети счастье», «ребенок маленькое чудо», «моя кровинка», «моя плоть и кровь», «ребенок ни в чем не виноват»). В общей картине размышлений эта категория заняла 26,1% (рис.3).

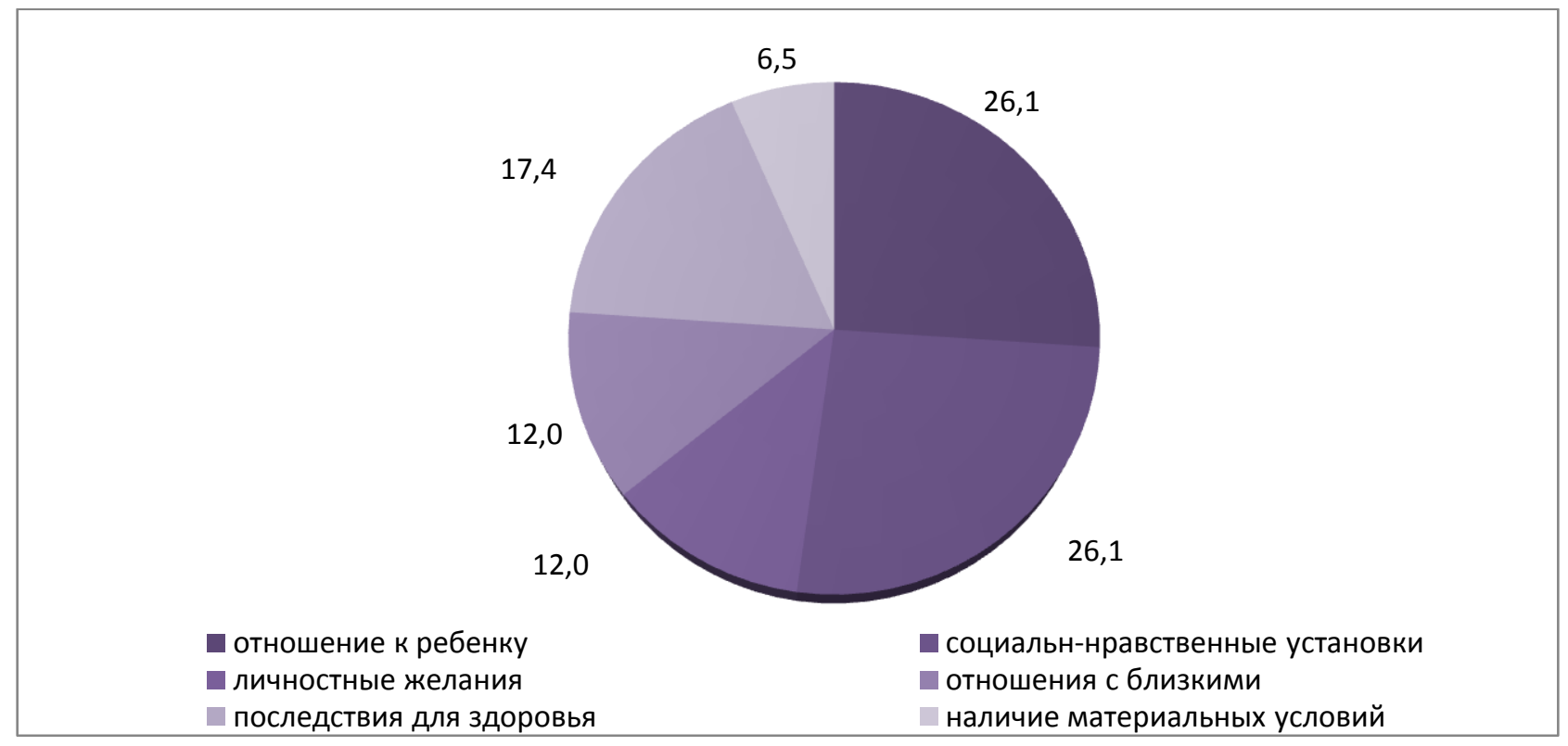

\section{Рис. 3. Основные группь мотивов сохранения жизни будущего ребенка}

Вторая категория - «соичально-нравственные установки»- объединила четыре линии размышлений: признание права ребенка на жизнь; отрицание убийства как такового и своей способности к его совершению («это преступление», «не могу убить»; наличие социальной ответственности и религиозные убеждения. Объем второй категории в общей совокупности суждений 26,1\%. Третья категория - «последствия для здоровья» - составила 17,4\%. К категории «личностные желания» были отнесены идеи «хочу стать мамой, «хочу создать семью», «иметь родного человека». Общий объем категории 12\%. Такой же, по количественным показателям, оказалась и категория «личностные отношения», объединившая размышления девушек о любимом человеке и возможности получить поддержку родных и друзей. Самой немногочисленной категорией, определяющей возможность принятия девушкой решения о сохранении незапланированной беременности, оказалась категория «материальных и бытовых условий» $-6,5$ \%.

Рассмотрим вопрос мотивационных истоков прерывания незапланированной беременности. Подчеркнем, что каждый седьмой участник опроса вообще отверг идею наличия мотивов, обуславливающих отказ от рождения ребенка. Остальные девушки $(83,6 \%)$ акцентировали внимание на четырех аспектах: здоровье, отсутствие возможности содержать и воспитывать ребенка, пережитое насилие, осуждение. Указывая на здоровье, девушки преимущественно оговаривали патологию плода. Формулируя свою позицию, многие 
подчеркивали, что решение обусловлено не боязнью ухода за «особенным» ребенком, а попыткой уберечь его от мучений. В целом угроза здоровью матери и ребенка, как мотив прерывания беременности, прозвучала в ответах трети участников опроса (27,5\%). Отсутствие надлежащих жилищных и материальных условий также преимущественно подавалось в социально одобряемой трактовке невозможности предоставить ребенку надлежащий уход и воспитание. Такой вариант мотивации был задекларирован 17,6\% участниц. Пережитое сексуальное насилие и осуждение со стороны наиболее близких и значимых людей, как мотивы прерывания беременности, избрали 27,4\% отвечающих (по $13,7 \%$ относительно каждой идеи). Мотивация осуждения объединила утверждения о непринятии и отказе от ребенка его потенциального отца, а также негативное отношение родителей девушки.

На основании проведенного опроса можно констатировать, что угроза бесплодия после прерывания беременности осознается молодежью и влияет на формирование ее позиций. При обсуждении вопроса о возможных последствиях аборта, большинство девушек $(88,5 \%)$ считают, что в ситуации незапланированной беременности лучше отдать предпочтение рождению малыша, нежели сохранению личностной свободы. Анализ отношения девушек к аборту свидетельствует, что в их сознании это явление ассоциируется со злодеянием. В большинстве высказанных суждениях об аборте $(74,5 \%)$, он интерпретируется как «грех», «преступление», «убийство», «ужас», «худшее, что может случиться в жизни». Для передачи остроты и значимости суждений многие девушки использовали прописные буквы и множественные знаки восклицания («Грех!!!, «Табу!», «Убийство»). При этом на физические и эмоциональные страдания девушки («боль, «страх»») внимание было обращено только в нескольких случаях (7,4\%). При нейтральноуравновешенном отношении к абортам (18,2\% от общего объема суждений) использовались два основных типы обоснований: «право» и «вынужденная необходимость».

Установки относительно принятия решений в ситуации незапланированной беременности значительным образом зависят от представлений молодежи о развитии личностных отношений. В сознании девушек присутствуют опасения относительно дальнейшего развития событий. Понимание того, что происшедшее повлечет изменения в отношениях, связано с опасением реакции партнера. Половина участниц опроса (45,9\%) считают, что развитие отношений может иметь две противоположные модальности: сближения (повышения ответственности и зрелости) и наоборот - постепенного или резкого угасания. $16,4 \%$ участниц вообще считают, что в такой ситуации можно ожидать острых конфликтов, агрессии, отказа от отцовства. Каждый десятый опрошенный считает, что даже при положительном развитии отношений вначале будет прослеживаться напряженность, дискомфорт, неопределенность. Только треть участниц $(26,2 \%)$ акцентировали свое внимание на положительных изменениях в отношениях, при этом четко оговаривая, что речь идет о влюбленных. Их отношения, в связи с зарождением новой жизни, поднимутся на новый уровень, появятся новые планы, люди станут более зрелыми и ответственными.

Таким образом, полученные результаты свидетельствуют о том, что неопределенность и опасения относительно дальнейшего развития отношений, являются важным детерминирующим фактором, определяющим поведение девушки в сложной, психотравмирующей ситуации незапланированной беременности. Правомерность таких опасений имеет статистическое подтверждение. Из 937 тыс. неполных семей, проживающих в Украине в 2020 году, в большинстве из них $(92,8 \%)$ ребенок воспитывается без отца (Державна служба статистики України, 2020, с. 7). По нашим данным, использование факта беременности с целью шантажа партнера для заключения брака не может иметь широкого распространения, поскольку воспринимается не только этически непорядочным, но и психологически нецелесообразным шагом. Большинство опрошенных девушек (96,8\%) категорически отвергли такой способ влияния на партнера, избрав оценочные позиции «не одобряю» $(52,5 \%)$ и «скорее не одобряю» $(44,3 \%)$.

Использование в исследовании «Опросника ролевых ориентаций деторождения» (авт. Родштейн) позволило подытожить наши наблюдения относительно диспозиционных 
установок девушек по изучаемому вопросу. Диагностический инструментарий позволил проанализировать сформированность личностных установок по двум шкалам: «генофилиягенофобия» (восприятие детей и всего, что связанно с ними, в качестве жизненной ценность; наличие желания иметь детей; готовность действовать на их благо) и шкала «репродуктивной активности-пассивности» (готовность родить ребенка независимо от наличия условий, поддержки, ухудшения материального благосостояния, нежеланной беременности).

Полученные результаты свидетельствуют, что 62,3\% респондентов имеют средний или выше среднего уровень сформированности ролевых ориентаций на деторождения. Низкие показатели за этими показателями диагностировано только у 9,8\% опрошенных. Сравнение результатов по двум шкалам (генофилия-генофобия; репродуктивная активностьрепродуктивная активность) позволяет утверждать, что показатели по этим конструктами близкие по значению. Как видно из табл. 2, в выборке отсутствуют респонденты, которые продемонстрировали высокий уровень сформированности установок. Показатели выше среднего уровня по обеим шкалами диагностировано у 27,9 \% участниц опроса. Средний уровень по шкале генофилия-генофобия имеют $39,3 \%$, по шкале репродуктивная активностьпассивность - 34,4\% девушек.

Таблийа 2

\section{Наполняемость подгрупп с разным уровнем сформированности репродуктивных установок}

\begin{tabular}{|l|c|c|}
\hline \multirow{2}{*}{\begin{tabular}{l} 
Уровни сформирован- \\
\cline { 2 - 3 }
\end{tabular}} & \multicolumn{2}{|l|}{ Показатели наполняемости подгрупп по шкалам } \\
\hline генофилия-генофобия & $\begin{array}{c}\text { репродуктивная } \\
\text { активность-пассивность }\end{array}$ \\
\hline выше среднего & 0 & 0 \\
\hline средний & 27,9 & 27,9 \\
\hline ниже среднего & 39,3 & 34,4 \\
\hline низкий & 23,0 & 26,2 \\
\hline
\end{tabular}

Изучение корреляционных связей между переменными ценностных ориентаций и установок личности показало, что стремление к материальному благополучию положительно связано с установкой на личностную свободу $(\mathrm{r}=0,516 ; \mathrm{p} \leq 0,01)$ и профессиональное становление $(\mathrm{r}=0,555 ; \mathrm{p} \leq 0,01)$. В то время как ролевые ориентации на деторождение имеют связь противоположной модальности с установками на материальное благополучие $(\mathrm{r}=-344$; $\mathrm{p} \leq 0,01)$ - чем выше стремление личности к материальному благополучию, тем менее значимой является ценность детей, их рождения и воспитания. Стремление к личностной свободе имеет слабую отрицательную связь с генофилией $(\mathrm{r}=-0,267 \mathrm{p} \leq 0,05)$. Ценность «дети» коррелирует с ориентацией личности на семью $(\mathrm{r}=0,508 ; \mathrm{p} \leq 0,01)$; любовь $(\mathrm{r}=0,365$; $\mathrm{p} \leq 0,01)$; установками на генофилию $(\mathrm{r}=0,452 ; \mathrm{p} \leq 0,01)$ и репродуктивную активность $(\mathrm{r}=0,428 ; \mathrm{p} \leq 0,01)$. Профессиональное становление обратно пропорционально связано с репродуктивной активностью $(\mathrm{r}=-329 ; \mathrm{p} \leq 0,01)$. Ценность семьи имеет существенную связь с переменной «любовь» $(\mathrm{r}=0,549 \mathrm{p} \leq 0,01)$, но при этом связь с ролевыми ориентациями на деторождение не прослеживается $(\mathrm{r}=0,212 ; \mathrm{p}>0,05)$.

Сопоставление ценностных ориентаций субъектов с разным уровнем сформированности ролевых ориентаций деторождения показало, что позиции респондентов статистически отличаются по ценностям «семья», «дети», «материальное благополучие». Чем выше уровень признания шкал генофилии и репродуктивной активности, тем более ярко прослеживается ориентация на семью и детей. Показатели признания ценностей «личностная свобода» и «профессиональное становление» у представителей разных уровневых групп сформированности ролевых ориентаций деторождения не отличаются. 
Таким образом, проведенное исследование показало, что ситуация незапланированной беременности, безусловно, имеет значительный психотравмирующий эффект для молодой девушки, вызывающий целый спектр негативных и амбивалентных эмоций. Но даже в ситуациях, отягощенных отсутствием поддержки со стороны любимого человека или сексуального насилия, ориентация на рождение ребенка, осознание его права на жизнь, сохраняет свою устойчивость. Приоритизация семейных ценностей, негативное отношение к искусственному прерыванию беременности, наличие сформированных репродуктивных установок создают условия, в которых молодая женщина в трудной ситуации делает выбор в пользу ребенка.

Важными направлениями последующих исследований мы считаем изучение установок мужской выборки относительно факта незапланированной беременности подруги, изучение влияния определённых демографических факторов (например, проживание в сельской местности, небольших городах, мегаполисах) на формирование установок; проведение кросс-культурных исследований.

\section{СПИСОК ССЫЛОК}

Аристотель, (2020). Избранные сочинения. Политика. Категории. Поэтика. Киев.

Васильченко, О. М. (2013). Репродуктивное поведение. Возможности диагностики. Вестник практической психологии образования, 2 (35), 119-125. Взято с https://psyjournals.ru/files/93201/vestnik_psyobr_2013_n2_Vasilchenko.pdf.

Данілова, Є. (2019). Кількість абортів в Україні у $\overline{2019}$ ройі зросла на 60\%. Взято 3 https:/greenpost.ua/news/kilkist-abortiv-v-ukrayini-u-2019-rotsi-zrosla-na-60-i9193

Державна служба статистики України, (2020). Соціально-демографічні характеристики домогосподарств України у 2020 році (за даними вибіркового обстеження умов життя домогосподарств) Статистичний збірник. Взято 3 http://www.ukrstat.gov.ua/druk/publicat/Arhiv_u/17/Arch_cdhd_zb.htm.

Карымова, О. С. (2010). Социально-психологические особенности репродуктивной установки бесплодных мужчин $u$ женщин. (Дис. канд. психол. наук). Оренбургский Государственный Университет. Взято с http://nauka-pedagogika.com/psihologiya-19-0005/dissertaciya-sotsialno-psihologicheskie-osobennosti-reproduktivnoy-ustanovkibesplodnyh-muzhchin-i-zhenschin.

Родштейн, М.Н. (2006). Гендерно-ролевая идентичность как фактор репродуктивной установки женщиин. (Дис. канд. психол. наук). Самарский Государственный педагогический Университет. Взято с https://www.dissercat.com/content/gendernorolevaya-identichnost-kak-faktor-reproduktivnoi-ustanovki-zhenshchin.

Туманова, Н. Н. (2009). Подростковая беременность как фактор риска формирования девиантного материнства. Учёные записки Санкт-Петербургского государственного института психологии и сощиальной работы, 1 (11), 87-91. Взято с https://notes.psysocwork.ru/text/info/podrostkovaja-beremennost-kak-faktor-riska-

formirovanija-deviantnogo-materinstva/.

Шишук, О. (2010). Соціально-психологічні характеристики та особливості психічних станів жінок із небажаною вагітністю. Проблеми сучасної психологї, 10. http://journals.uran.ua/index.php/2227-6246/article/view/161805.

\section{REFERENCES}

Aristotel, (2020). Izbrannyye sochineniya. Politika. Kategorii. Poetika[Collected works. Politics. Categories. Poetics]. Kyiv. [In Russian].

Vasilchenko, O. M. (2013). Reproduktivnoye povedeniye. Vozmozhnosti diagnostiki [Reproductive behavior. The possibilities of diagnostics]. Vestnik prakticheskoy psikhologii obrazovaniya, 2 (35), 119-125. Vzyato z $\quad$ z 93201/vestnik_psyobr_2013_n2_Vasilchenko.pdf. [In Russian]. 
Danilova, C. (2019). Kilkist abortiv v Ukraïni u 2019 rotsi zrosla na 60\% [In Ukraine the amount of abortions is increased by $60 \%$ in 2019]. Vzyato z https://greenpost.ua/news/kilkist-abortiv-vukrayini-u-2019-rotsi-zrosla-na-60-i9193/. [In Ukrainian].

State Statistics Service of Ukraine, (2020). Socio-demographic characteristics of households in Ukraine in 2020 (according to a sample survey of living conditions of households) Statistical collection. Vzyato z http://www.ukrstat.gov.ua/druk/publicat/Arhiv_u/17/Arch_cdhd_zb.htm. [In Ukrainian].

Karymova, O. S. (2010). Sotsialno-psikhologicheskiye osobennosti reproduktivnoy ustanovki besplodnykh muzhchin $i$ zhenshchin [Social and psychological features of reproductive attitudes of infertile males and females]. (Dis. kand. psikhol. nauk). Orenburgskiy Gosudarstvennyy Universitet. Vzyato z http://nauka-pedagogika.com/psihologiya-19-0005/dissertaciya-sotsialno-psihologicheskie-osobennosti-reproduktivnoy-ustanovkibesplodnyh-muzhchin-i-zhenschin. [In Russian].

Rodshteyn, M. N. (2006). Genderno-rolevaya identichnost kak faktor reproduktivnoy ustanovki zhenshchin [Gender-based role identity as a factor of women's reproductive attitudes]. (Dis. kand psikhol. nauk). Samarskiy Gosudarstvennyy pedagogicheskiy Universitet. Vzyato z https://www.dissercat.com/content/genderno-rolevaya-identichnost-kak-faktor-

reproduktivnoi-ustanovki-zhenshchin. [In Russian].

Tumanova, N. N. (2009). Podrostkovaya beremennost kak faktor riska formirovaniya deviantnogo materinstva [Teenage pregnancy as a risk factor in forming deviant motherhood]. Uchenyye zapiski Sankt-Peterburgskogo gosudarstvennogo instituta psikhologii i sotsialnoy raboty, 1 (11), 87-91. Vzyato z https://notes.psysocwork.ru/text/info/podrostkovaja-beremennost-kakfaktor-riska-formirovanija-deviantnogo-materinstva/. [In Russian].

Shyshuk, O. (2010). Sotsialno-psykholohichni kharakterystyky ta osoblyvosti psykhichnykh staniv zhinok iz nebazhanoiu vahitnistiu [Social and psychological characteristics and features of mental states of women with unwanted pregnancy]. Problemy suchasnoi psykholohii, 10. Vzyato z http://journals.uran.ua/index.php/2227-6246/article/view/161805. [In Ukrainian].

\title{
YOUTH'S ATTITUDES TOWARDS UNINTENDED PREGNANCY
}

\author{
Nataliia Korchakova \\ Doctor of psychological sciences, professor, \\ Department of Developmental and Pedagogical Psychology \\ Rivne State University of the Humanities \\ https://orcid.org/0000-0003-1164-3370 \\ Valentyna Bezliudna \\ Candidate of pedagogical sciences, professor, \\ Department of developmental and Pedagogical Psychology \\ Rivne State University of the Humanities \\ https://orcid.org/0000-0003-3276-3427
}

DOI https://doi.org/10.35619/praprv.v1i16.207

The paper deals with an issue of youth's attitudes towards unintended pregnancy. Studying the psychological basis of a woman's decision about the fate of her unborn child is of great social and ethical significance for the modern society. 86 participants at their early adulthood $(M=20,2)$ were involved into the research. To explore their attitudes we used the Questionnaire of role-based orientations towards childbirth (ROD) (author Rodstein), the Questionnaire "Unintended pregnancy" (author Korchakova) and Standardized interview for studying reproductive attitudes (author Karymova). Our results have shown that young Ukrainian women follow family-oriented attitudes. They tend not to accept being in relationship without official marriage (about $32.9 \%$ 
demonstrated strong disagreement and only $12 \%$ demonstrated the high level of accepting the idea of civil partnership). However, they do not condemn the premarital sexual relationships (only $8 \%$ participants were intolerant to that kind of relationships). Content analysis of emotional states, associated with the realizing the fact of unwanted pregnancy, revealed the dominance of negative thoughts and emotions among the participants. They declared fear, stress, panic, confusion. However, 35,6\% of respondents have positive association with a child birth. All attitudes we divided into 3 subgroups: positive, negative and philosophically neutral.

Taking into account the influence of social and moral values on the process of making decision, we asked participants to estimate 6 social values: "personal freedom», "economic wellbeing», "children», "professional development», "family» and «love». Our respondents considered the most valuable among them «family», "love» and "children». Those family-oriented attitudes underlay the dominance of option "to give birth» (86\%) instead of "to eliminate an unintended pregnancy» (14\%) in respondent's answers. It worth to note, that the option "to give birth and put a child up for adoption» has not been chosen. Young women do not consider that option as a way to cope with the situation.

Another factor that, in our opinion, might influence woman's choice was the father's characteristics. Our respondents estimated the appropriateness of having a child with 3 types of men: «loving partner», "casual partner» and «abuser». It was predictable, that the first type was highly rated to have child together. Surprisingly, in a case of casual partner or abuser less than half of respondents preferred not to have a child with such types of fathers $(38,4 \%$ and 48,8\% respectively). Moreover, even in a case of assault, about 13,9\% women declared the high level of appropriateness to give birth.

In our opinion, future research could continue to explore the youth's attitudes towards unintended pregnancy in a male sample or observe cross-cultural differences.

Key words: unintended pregnancy, reproductive attitudes, childbirth, social values. 